\title{
LA LUCHA DE LOS SANTOS. CORPORACIONES E IMÁGENES RELIGIOSAS VINCULADAS A LA INUNDACIÓN DE 1629 EN LA CIUDAD DE MÉXICO
}

\author{
Mario Hugo CuÉllar MelÉNDEZ \\ Escuela Nacional de Antropología e Historia/INAH \\ marinhosalsa@hotmail.com
}

\section{Resumen}

Las inundaciones sufridas por los habitantes de la Ciudad de México a principios del siglo XVII animaron una serie de explicaciones en donde se conjugaban simultáneamente razonamientos naturales, sociales y religiosos en la búsqueda por entender por qué la ciudad se inundaba y cómo se podía enfrentar semejante riesgo. Las inundaciones eran percibidas como el resultado del sitio donde se fundó la ciudad y las actividades económicas desarrolladas después de la Conquista; pero también prevalecía la idea de que eran la consecuencia de un castigo divino. Las formas de responder a la amenaza de inundación se manifestaron en ambos sentidos, pero las inundaciones ocurridas en las primeras décadas del siglo XVII, especialmente la inundación de 1629, revitalizaron la perspectiva punitiva que traía implícitas respuestas relacionadas a pedir la intercesión de los santos y vírgenes. En los momentos de crisis una «lluvia de santos y vírgenes» fueron propuestos por diversas corporaciones con el objetivo de que alguno de ellos fuera reconocido como el mejor patrón contra las inundaciones. En un contexto conflictivo y caracterizado por la constante presencia de la amenaza de inundación, estas imágenes jugaron un papel importante en el reacomodo político y social posterior a la coyuntura de inundaciones de principios del siglo XVII.

Palabras clave: Inundaciones; Ciudad de México; Imágenes Religiosas;

Corporaciones; Inundación de 1629 


\begin{abstract}
The struggle of the saints. Corporations and religious images linked to the 1629 flood in Mexico City

The floods suffered by the inhabitants of Mexico City at the beginning of the XVII century animated a series of explanations where natural, social and religious reasoning was simultaneously conjugated in the search of understanding why the city flooded and how such risk could be faced. Floods were perceived as the result of the site where the city was founded and the economic activities developed after the Conquest; but the idea that they were the result of a divine punishment also prevailed. The ways to respond to the threat of the flood were manifested in both senses, but the floods which happened in the early decades of the XVII century, especially the 1629 flood, invigorated the punitive perspective which carried implicit responses related to asking the intercession of saints and virgins. In the moments of crisis a «rain of saints and virgins» were proposed by diverse corporations with the objective that either of them was recognized as the best patron against floods. In a context both conflictive and characterized by the constant presence of the threat of floods, these images played an important role in the political and social realignment posterior to the juncture of floods at the beginning of the XVII century.
\end{abstract}

Keywords: Floods; Mexico City; Religious Images; Corporations; 1629 Flood.

Sepan los de México que por respeto de mi Madre no acabo con esta Ciudad, que le agradezcan este beneficio, y que se parten de ofenderme por su amor, pues yo por amor de ella me aparto de castigarlos ${ }^{1}$.

Las inundaciones sufridas por los habitantes de la ciudad de México a principios del siglo XVII animaron una serie de explicaciones en donde se conjugaban simultáneamente razonamientos naturales, sociales y religiosos en la búsqueda por entender por qué la ciudad se inundaba y cómo se podía enfrentar semejante riesgo. Así, desfilaron posturas en el orden que hoy podríamos catalogar como científicas; funcionarios, ingenieros, frailes y religiosos entendían las inundaciones como consecuencia del lugar físico donde se hallaba asentada la capital virreinal e, incluso, no faltó quien adjudicara culpabilidades a ciertas actividades cotidianas introducidas por los españoles o surgidas

1. VELASCO, 1845: 103.

Revista de Historia Moderna, n. ${ }^{\circ} 35$ (2017) (pp. 149-177) | ISSN-e: 1989-9823 | ISSN: 0212-5862 
como consecuencia del nuevo orden impuesto posterior a la Conquista. La ganadería, la constante tala de árboles y la siembra intensiva en las laderas montañosas, por ejemplo, se traducían en una constante disminución de la capacidad de los lagos por retener agua en sus lechos, asunto que provocaba las inundaciones ${ }^{2}$. Las respuestas asociadas a este tipo de explicaciones animaron proyectos que pretendían impactar en los lagos por medio de su transformación, como el desagüe; o por medio de obras hidráulicas que defendieran a la ciudad, como la reconstrucción de calzadas. Los ganados se mudaron al norte de la Cuenca, pero fue más difícil controlar a los leñadores furtivos y a los escurridizos agricultores.

Si bien, las explicaciones «científicas» alentaron políticas concretas que intentaban remediar el problema, estas siempre estuvieron acompañadas de elementos religiosos y creencias inspiradas en la biblia. Un ejemplo lo encontramos en las primeras fojas de la Relación Universal, manuscrito impreso en 1637 con el objetivo de dar solución al problema de las inundaciones en la ciudad justamente durante la resaca provocada por la Gran Inundación de $1629^{3}$. En un párrafo, el primero de cientos de fojas, la Relación inicia con una puntual descripción del sitio donde se encontraba la ciudad; subraya la cercanía de los montes y serranías, de los ríos y cómo estos vertían sus aguas en los lagos. Además, menciona cómo las labores y el arado de la tierra habían propiciado la estrechez del vaso del lago que rodeaba a la ciudad. Una explicación precisa y clara que responde al orden natural. Sin embargo, en las fojas preliminares se lee un soneto al virrey Marqués de Cadereyta donde habla en primera persona la Ciudad de México y donde se hace alusión a San Gregorio Taumaturgo, primer santo patrono contra las inundaciones.

2. Por ejemplo, Enrico Martínez, primer Maestro Mayor del Desagüe, argumentaba en 1606 que «después que este Reino está poblado de cristianos», se comenzó arar en todas partes "y la huella de continuo el ganado y los caballos, es causa de estar movida [la tierra]». El efecto de esto era que los aguaceros que caían en los llanos arrastraban «mucha lama y tierra la cual se asienta en las partes más bajas». Ver en MARTínEZ, 1606: 185-186.

3. La «Gran Inundación» es un término que tomo del historiador Richard Boyer quien llamó así a la inundación de 1629. Empero, el proceso de anegamiento de la ciudad de México habría comenzado desde 1626 y continuó hasta 1635, incluso sus estragos podían observarse años después de esa fecha. Ver en BOYER, 1975. 


\section{Después de aquella lamentable ruina \\ Restauradas aguardo mis fortunas \\ En el desuelo tuyo o gran Licurgo, \\ Mi tutelar podrás, con fe divina, \\ Trasladar montes, apurar lagunas, \\ Ser a mis votos nuevo Taumaturgo ${ }^{4}$.}

En esta lógica, algunos años antes, el cronista e ingeniero franciscano fray Juan de Torquemada imprimía una explicación religiosa a unas inundaciones que entendía como el resultado del desvío de ríos, la desecación de zonas lacustres y la proliferación de haciendas agrícolas ${ }^{5}$. Para el religioso, los lagos de México eran reminiscencias del Diluvio Universal y los indios, habían sido condenados a vivir en el agua a causa de sus pecados abominables, pero también a perecer en la guerra de Conquista ${ }^{6}$. Los apuntes de Torquemada traían implícita una idea profunda que nos acerca al pensamiento de la época: las inundaciones eran el resultado del castigo divino. Desde los primeros párrafos del génesis, esta circunstancia había quedado clara. El Viejo Testamento enseñaba que Dios Padre había castigado a la humanidad tras decepcionarse de los hombres y darse cuenta que sus pensamientos tendían siempre al mal. Así, del fondo de los mares hizo brotar manantiales y las compuertas del cielo se abrieron dejando caer sobre la tierra un aguacero que duró cuarenta días y cuarenta noches. El agua cubrió los montes más altos ahogando a todos los animales, aves, reptiles y a la humanidad entera. Solo salvó la vida la familia de Noé y las criaturas que subieron al arca que la divinidad había ordenado construir. La inundación bíblica no es otra cosa que el "peor castigo», el "gran castigo» o el «castigo por excelencia» de Dios hacia la humanidad corrupta. Era una depuración ante el mal comportamiento de su creación más querida.

Ante la incapacidad de entender los lagos de México, es probable que la idea vertida por Torquemada fuera popular, sobre todo entre la población de origen español avecindada en la ciudad durante el siglo XVI y XVII. Todavía en el siglo XVIII, nos dice Alain Musset, la mayoría de las personas no podían

4. Cepeda, Carrillo y Álvarez, 1982: II.

5. Las observaciones de Torquemada fueron hechas a principios del siglo XVII. Para él, el estado del lago era tan crítico que, si no lloviera, sentenciaba el fraile, el agua «de todo punto faltara». TORQUEMADA, 1975: 423.

6. TORQUEMADA, op. cit. I, p. 422. 
entender con claridad la existencia de un lago con las características que tenía aquel que rodeaba a la ciudad de México. La altura en la que se hallaba, la diversidad de sabores, colores y olores que expedía, la ausencia de una boca o «desaguadero» natural y otros elementos como las fluctuaciones imprevistas y los oleajes cotidianos, inflamaron la imaginación supersticiosa de los españoles. No faltó quién comparara las formas del lago con la imagen de la bestia del Apocalipsis descrita por San Juan ${ }^{7}$.

Durante el complejo proceso de entender la existencia del lago, surgió, además, otra idea que reafirmaba el origen punitivo del agua que rodeaba a la ciudad de México. Varias crónicas y cronistas del siglo XVI y principios del siglo XVII señalan que, con la llegada de los españoles, es decir, de la cristiandad, los lagos comenzaron a menguar. Uno de los primeros en darse cuenta de este fenómeno fue el franciscano fray Toribio de Benavente Motolinía quien fue testigo presencial de este hecho y dio testimonio al escribir que «en el tiempo de Moctezuma, y cuando los españoles vinieron a ella [a la ciudad de México], estaba toda muy cercana de agua y desde el año de 1524 siempre ha ido menguando $»^{8}$. Esta idea podía interpretarse como una manifestación de que la ira divina se aplacaba con la conquista de aquellos pueblos bárbaros y sanguinarios: Si el Dios cristiano había hecho retroceder las aguas después del diluvio, en México se conservó buena parte debido al mal comportamiento que mostraban los indios inclinados a escuchar falsos dioses y demonios que exigían los sacrificios más horribles como aquellos descritos por fray Bernardino de Sahagún o fray Diego Durán; sacrificios relacionados, además, al agua y que incluían la inmolación de niños cuyos corazones eran arrancados y arrojados en las lagunas para pedir lluvia ${ }^{9}$.

En síntesis, el Diluvio Universal jugó un papel importante a la hora de entender las inundaciones. Ya Motolinía se sorprendía, a principios de la

7. MUSSET, 1992: 135.

8. BenAVEnTe Motolinía, 1914: 191. El énfasis es mío.

9. Sahagún apunta que, durante el atlcahualco, los mexicanos «mataban muchos niños: sacrificábanlos en muchos lugares y en las cumbres de los montes, sacándoles los corazones a honra de los dioses del agua, para que les diesen agua o lluvias». Ver en SAHAGÚN, 1992: 77. Fray Diego Durán describió la inauguración del acueducto de Coyoacán en tiempos del rey Ahuízotl. Al recibir el agua, en la entrada de la ciudad, "tenían junto a ella cuatro niños de a seis años, todos embijados de negro y la frente azul». Cuando llegó el agua, el primero de ellos fue acostado; le abrieron el pecho y le extirparon el 
época colonial, de la grandeza y altura de los montes que rodeaban a la ciudad y se preguntaba cómo, durante el diluvio bíblico, estos pudieron quedar sumergidos en el agua. Uno de estos montes, además, tenía una boca de fuego que humeaba constantemente y los indios lo llamaban Popocatépetl: «sierra que echa humo». Las fumarolas del volcán eran tan altas y gruesas como «la torre de la iglesia mayor de Sevilla»: Era la boca del infierno que quedó cegada en 1528, unos años después de que los españoles habían refundado la ciudad de México ${ }^{10}$. El detrimento de los lagos y la ausencia de fumarolas en el volcán Popocatépetl podían percibirse como señales divinas que embonaron a la perfección con el pensamiento milenarista de los frailes evangelizadores que llegaron a principios del siglo XVI, sobre todo de los franciscanos. Así, la Conquista y evangelización fueron justificadas, pues ambas eran parte de un plan providencial que tenía manifestaciones concretas en los cambios del medio ambiente. Aplacada la ira de Dios, la antigua ciudad era símbolo de la esperanza; la Nueva Jerusalén de Motolinía: «Tú que antes eras muestra de pecados, ahora eres enseñadora de verdad, tú que antes estabas en tinieblas y oscuridad, ahora das resplandor de doctrina y cristiandad ${ }^{11}$.

Pero la percepción negativa e incluso demoniaca de los lagos continuó a lo largo de los siglos gracias a la presencia constante de la amenaza de inundación. En la medida en que los lagos disminuían, las inundaciones eran más recurrentes y sus efectos más desastrosos para los habitantes de la ciudad. La crisis se precipitó en las primeras décadas del siglo XVII cuando nos encontramos no solo testimonios que hablan del detrimento de los lagos, sino también la construcción del desagüe de la Cuenca de México; pero también se documentaron procesos de inundación en 1604-1607, 1620 y el terrible proceso de 1626-1634 que trajo consigo la Gran Inundación ocurrida en 1629 ¿Cómo explicar semejante contradicción? Lo que ocurrió fue una sorprendente lluvia de papeles, pesquisas, pareceres, proyectos, críticas y opiniones emanadas por decenas de personas que intentaban poner remedio a las inundaciones a partir de explicar el origen natural de las mismas. Ríos de tinta que

corazón. A manera de ofrenda dejaron que el músculo tuviera contacto con el agua y la sangre se derramara dentro del caño. Ver en: DURÁN, 1867: 390.

10. BENAVENTE, op. cit. p. 183.

11. Ibídem, p. 181. 
poco ayudaron pues confundían a las autoridades y retrasaban las decisiones. Pero también ocurrió una revitalización de la idea de que las inundaciones eran el resultado de un castigo divino ya no por los pecados de los indios cometidos antes de la cristiandad, que habían servido de chivo expiatorio para explicar la presencia de los lagos, sino de los entonces habitantes de la ciudad de México. A finales del siglo XVII, el gran pensador mexicano Carlos de Sigüenza y Góngora escribía su Alboroto y motín en México del 8 de junio de $1692 \mathrm{y}$, aunque el texto plantea todo lo relacionado al tumulto por falta de alimentos que vivió la ciudad a finales del siglo XVII, también habla de las inundaciones desde una perspectiva apocalíptica.

[...] instaron ellas [las lluvias] en arruinar México, y habiendo sido por uno de aquellos medios de que Dios se vale para castigar a los impíos y reducir el camino de la justicia a los que lleva extraviados la iniquidad, yo no dudo que mis pecados y los de todos le motivaron a que, amenazándonos como padre con azote de agua, prosiguiese después el castigo con hambre por nuestra poca enmienda ${ }^{12}$.

En 1631 una posición semejante era expresada por el marqués de Gelves quien había sido virrey de Nueva España entre 1621 y 1624. Las relaciones de aquel funcionario con las corporaciones de la ciudad de México habían sido tensas al grado que en enero de 1624 los conflictos que sostuvo con el arzobispo habían detonado el motín que finalmente lo derrocó. La opinión de Gelves es parcial pues, a sus ojos, los habitantes de Nueva España, principalmente sus autoridades, eran corruptas e indomables. Así, cuando se le consultó para analizar la posible mudanza de la ciudad de México durante la inundación de 1629, Gelves apoyó la propuesta con ahínco. Para el viejo funcionario la inundación que devastó la ciudad era la consecuencia inmediata de un castigo "contra aquellos que no se dejaban enmendar por el virrey ${ }^{13}$. Posturas similares sobre la corrupción de los políticos novohispanos las encontramos en algunos tratadistas de la época. Había crisis en España y una generación nueva de funcionarios puritanos, como Juan de Palafox y Mendoza, veían una progresiva decadencia como consecuencia del deterioro moral que impactaba todos los órdenes sociales.

12. SigÜENZA y GÓNGORA, 1972: 122. El énfasis es mío.

13. MUSSET, 2011: 286. 
Lo cierto es que entender las inundaciones desde la perspectiva punitiva traía implícitas respuestas relacionadas a la intercesión de los santos y vírgenes. El objetivo era calmar la ira de Dios y ellos, como seres que en algún momento fueron terrenales, tenían mayor capacidad de entender los pecados humanos e influir en la divinidad para apaciguar las aguas o cualquier otra amenaza. Lo interesante es que esta idea fue plasmada por algunos pensadores de la época como Pedro Ciruelo quien, en 1628, estipuló una regla para ser acatada por todos los buenos cristianos temerosos de Dios, de su conciencia y celosos de su salvación. En ella decía que, ante las adversidades resultado de sus pecados, el creyente debía hacer dos diligencias. La primera consistía en tratar de remediar lo más posible por la vía «natural del saber humano»; la segunda, encomendarse a Dios «y a sus santos con devoción su persona, familia, y hacienda, y suplicarle que en aquel trabajo socorra con ayuda celestial en lo que no alcanzan las fuerzas naturales, ni saber de los hombres ${ }^{14}$. En la ciudad de México las inundaciones estimularon la devoción hacía varias imágenes religiosas de santos y vírgenes a principios del siglo XVII, precisamente en la coyuntura que se caracterizó por la ocurrencia de varios procesos de inundación que comenzó en 1604 y terminó en 1634. Sin embargo, podemos identificar tres momentos precisos en que estas imágenes fueron veneradas y se les encomendaba la intercesión con Dios: A principios del siglo XVII; durante la Gran Inundación y algunos años después de la misma. Cada imagen representaba entonces a una corporación política, a un grupo en particular o a intereses concretos y delineados. Identificar las posturas políticas atrás de cada santo o virgen es apasionante y merece estudios profundos alrededor de ello. Aquí me detendré poco en este asunto y me enfocaré en hablar de los santos elegidos para ayudar en la salvación de la ciudad de México amenazada por inundaciones y de las corporaciones que estuvieran tras ellos.

\section{Antes de la Gran Inundación: Los primeros santos}

El primer santo elegido como «abogado de las aguas» y patrono de la ciudad frente a las inundaciones fue San Gregorio Taumaturgo. En el periodo

14. Ciruelo, 1628:108. 
comprendido entre 1604 y 1607 abundan, en las actas de cabildo, diversas sesiones para organizarlas festividades necesarias para su culto e inclusive construir una capilla dedicada a él. La constante presencia de estas discusiones muestra la preocupación del ayuntamiento, del cabildo eclesiástico y del virrey para revertir y dar remedio al problema de las inundaciones que padecía la ciudad de México, sobre todo aquellas relativas a las inundaciones de 1604-1607. A la par que en Huehuetoca se construía el desagüe, en la catedral de México se levantaba una capilla a este santo que, en vida, fue el primer obispo de Neocesarea en Turquía en el siglo III después de Cristo, se le adjudicaban varios milagros relacionados con el agua. Por ejemplo, se dice que siendo obispo puso:

[...] freno y termino al rio Lico, muy caudaloso, y furioso, que saliendo de madre arruinaba, y destruía toda aquella tierra donde pasaba. Vinieron los pueblos de aquella comarca a San Gregorio; dijeronle los daños grandes que recibían de aquel rio cuando se desenfrenaba, y creciendo con las avenidas, se extendía por los campos [...] y que todos los remedios que habían usado, no habían sido de provecho ${ }^{15}$.

San Gregorio Taumaturgo "el hacedor de milagros», según cuenta esta leyenda, fue al río y encajó en la ribera su báculo mientras exclamaba plegarias a Dios para que jamás el agua trascendiera de ese límite. Al poco tiempo su báculo «prendió en la tierra y se hizo un árbol grande: y cuanto más soberbio» y desde entonces el río nunca pudo pasar de ese obstáculo. El poder de influir en las aguas que los fieles españoles concedían a San Gregorio era tal que se decía que incluso el mismo mar había caído bajo su control tan solo con decirle «Hasta aquí llegaras, y aquí se quebraran tus furiosas ondas» ${ }^{16}$.

En la ciudad de México su devoción alcanzó su clímax antes de la inundación de 1629. En las Actas de Cabildo de septiembre de 1607, a la par de la discusión del desagüe, los regidores pidieron a las autoridades eclesiásticas que nombraran a dos personas encargadas de organizar una cofradía en su honor $^{17}$ y la capilla fue inaugurada el 17 de noviembre de 1610. A partir de

15. RIBADENEYRA, 1716: 220.

16. Ídem.

17. Archivo Histórico de la Ciudad de México (en adelante AHCM), Ayuntamiento de la ciudad de México, Actas de Cabildo, volumen 356-A, y actas de cabildo del 15 de noviembre de 1604 y septiembre de 1607. 
este momento, se hizo oficial su fiesta y su culto se extendió hasta que se le consideró incapaz de influir durante la Gran Inundación. A un mes de que se presentara el famoso aguacero del 21 de septiembre de 1629, los regidores habían ordenado encender durante ocho días seis cirios a la imagen del santo, "patrón y abogado de esta ciudad para que lo sea en esta ocasión con su divina majestad suplicándole la mire con ojos de piedad»; medida desesperada pues el agua se acercaba peligrosamente a la ciudad y en el Golfo de México se habían avistado barcos con banderas enemigas ${ }^{18}$. Durante la crisis su capilla fue ricamente adornada y perfumada, se le organizaron misas «cantadas», procesiones y novenarios ${ }^{19}$. En octubre, a pesar de que la ciudad estaba sufriendo un proceso de abandono y varios de sus edificios estaban en ruinas, no importó la falta de recursos para organizarle su fiesta con procesión alrededor de la Catedral, novenario y «todo lucimiento gastándose en ella todo lo necesario [...] poniéndose en el altar mayor mucha cera ${ }^{20}$. Sin embargo, el agua no bajó e, incluso, en 1630 volvió a subir por lo que la devoción a San Gregorio perdió vigor en la medida en que se le consideró menos capaz que otros santos y vírgenes para contener las aguas.

La imagen de San Gregorio Taumaturgo careció de vínculo específico con alguna corporación. Aunque los responsables de organizarle procesiones y pagar la cera y demás cosas necesarias para su veneración eran los regidores del cabildo, la imagen se encontraba en catedral y no en alguna capilla administrada directamente por el ayuntamiento. Era un santo reconocido por todos que no representaba a un grupo particular, ni el clero secular ni el cabildo de la ciudad. Todavía en 1637, como se dijo, se le menciona en la Relación Universal, pero su culto comenzó a desaparecer en la segunda mitad del siglo XVII hasta extinguirse por completo. Hoy en día, desconozco si su imagen permanece en Catedral o en alguna iglesia de la ciudad.

A diferencia de San Gregorio, la Virgen de los Remedios, "Aquella que cura los males» estuvo siempre vinculada al ayuntamiento de México. Fue considerada la patrona de la ciudad en algún momento del siglo XVI, probablemente

18. AHCM, Ayuntamiento de México, Actas de Cabildo, volumen 660-A, Libro 27, Acta de Cabildo del 20 de agosto de 1629, p. 122.

19. AHCM, Ayuntamiento de México, Actas de Cabildo, volumen 660-A, Libro 27, Acta de Cabildo del 27 de agosto de 1629, p. 124.

20. Ibídem. p. 155. 
en 1574 cuando García de Albornos, regidor y obrero mayor de la ciudad, la encontró en una vieja ermita improvisada por los indios durante una inspección a las canteras cercanas a Naucalpan y Tacuba. Fue entonces cuando el ayuntamiento decidió tomar el patronato de la imagen que fue, sin duda, una de las más importantes del periodo virreinal en la ciudad de México ${ }^{21}$.

La tradición cuenta que aquella pequeña escultura de madera había acompañado a los conquistadores en los momentos más difíciles de la guerra de Conquista, incluso, hubo artistas que la pintaron con cetro de mando y al Niño de su brazo con una espada en la mano. En Puebla, donde la imagen tuvo un impacto social relevante, se le conoce como la Virgen Conquistadora y no ha faltado quien argumente que la poblana es la imagen original. También se dice que, durante aquel mítico encuentro entre Hernán Cortés y Moctezuma, un soldado la portaba entre sus ropas y antes de que el conflicto se agravara permanecía en el Templo Mayor de Tenochtitlán pues fue la primera imagen religiosa que los españoles trajeron a la ciudad. Otra tradición relata que, durante la Noche Triste, en un lugar desconocido a las afueras de Tacuba, los españoles la abandonaron en un maguey con la esperanza de que la virgen los sacara de apuros en la persecución a la que estaban siendo sometidos. Los indios la habrían confundido con Mayahuel, diosa prehispánica asociada al pulque, y detuvieron el embate para adorarla, permitiendo a los españoles escapar de una muerte segura. También se cuenta que la imagen estuvo extraviada muchos años, hasta que un indio principal de la región de Naucalpan, Juan Cecuauhtli, la encontró en 1554 o 1555 en un cerrito donde se construyó su ermita ${ }^{22}$.

En su libro Baluartes de México, Mariano Fernández de Echeverría y Veytia, expone a la Virgen de los Remedios como una de las cuatro vírgenes que tenían santuarios extramuros a la capital, una en cada punto cardinal. A Remedios le correspondía el poniente, a la Guadalupana el Norte, a la Virgen de La Bala el oriente y a Nuestra Señora de la Piedad el sur. La única de estas vírgenes que no estuvo vinculada las inundaciones fue la Virgen de la Bala, pero el culto a la Virgen de los Remedios en realidad estaba relacionada a

21. AHCM, Ayuntamiento de México, Actas de Cabildo, volumen 637-A, Libro 8, Acta de Cabildo del 30 de abril de 1574, pp. 110 y 111.

22. FERNÁNDEZ ECHEVERRÍA, 1820: 63. 
las peticiones de lluvia y se le organizaban novenarios y procesiones cuando faltaba agua. Fray Luís de Cisneros apuntaba, en 1616, que en la ermita se hallaba una pintura donde se podía leer: «Cerrada queda la fuente, y con traza no entendida, nos das las aguas de vida ${ }^{23}$. También reporta al menos tres grandes procesiones que salieron de su ermita en Naucalpan hasta la catedral de México, dos de ellas en periodos de ausencia de lluvia, otra a causa de las epidemias de finales del siglo XVI. En 1597 las lluvias se retrasaron. Para el mes de agosto aún no llovía en la ciudad y en sus alrededores «la tierra abría mil bocas pidiendo al cielo agua, el ganado las cerraba con el último aliento porque les faltaba el beber y con que pudiesen brotar los pastos de las entrañas de la tierra». Se sacó la imagen en procesión hacía la catedral de México y

[...] apenas llegó la Virgen al paraje de la Huerta del Marqués, cuando comenzó el tiempo a ablandar, a arrebolarse el sol de nubes pardas, a obscurecerse y a empañarse esa media región, a empreñarse de agua, de manera que dentro de poco tiempo cayó un aguacero tan grande, tan copioso y largo, que habiendo estado la tierra tan seca, quedó tan mojada y empapada que corrían por todo el camino arroyos copiosos de agua, de manera que impedía la venida de la Virgen ${ }^{24}$.

Es común encontrar en las actas de cabildo solicitudes de procesión hechas por los pueblos indios a inicios de la temporada de lluvias. Es probable que la Virgen de los Remedios sustituyera a algunas deidades prehispánicas relacionadas al agua, al menos en algunas partes de la Cuenca de México y de la región de Cholula donde se encontraba otro santuario arriba de la pirámide principal, y las solicitudes llevadas al cabildo fueran una yuxtaposición de toda la parafernalia ceremonial que indicaba el inicio del ciclo agrícola mesoamericano antes de la llegada de los españoles. Margarita Nolasco, en sus estudios sobre los pueblos indígenas del área de Cholula, apuntaba, en la década de los setenta, que existían ciertas tradiciones orales que ligaban a la Virgen de los Remedios con una serpiente de agua y que es posible vincular su culto con antiguos ritos prehispánicos relacionados con el agua ${ }^{25}$. Asimismo,

23. CiSNEROS, 1999: 98.

24. Ibídem., p. 148.

25. NOLASCO, 1970: 249.

Revista de Historia Moderna, n. ${ }^{o} 35$ (2017) (pp. 149-177) | ISSN-e: 1989-9823 | ISSN: 0212-5862 
su fiesta era a principios de octubre, justamente cuando se pedía que no hubiera más lluvias pues estas solían traer granizo que aniquilaba las parcelas.

Lo cierto es que la virgen era reconocida como intercesora de los agricultores para que del cielo descendiera la lluvia necesaria, en una sociedad predominantemente agrícola, estos favores eran especialmente importantes. Sin embargo, en agosto de 1629, en la medida en que los lagos se acercaban peligrosamente a la ciudad y amenazaban anegarla, los regidores desesperados decidieron postularla como intercesora de la ciudad para evitar la inundación, al fin de cuentas, era la Virgen de Los Remedios, a la que el devoto se inclinaba para pedir el remedio a sus males. Entonces, se organizó un novenario urgente en la ermita de Naucalpan, se hizo una pequeña procesión alrededor del atrio y se descubrió el rostro de la imagen ${ }^{26}$. Días después, sobrevino el aguacero que inundó la ciudad. Al igual que pasó con San Gregorio Taumaturgo, la Virgen de los Remedios fue perdiendo importancia como intercesora en estas cuestiones pues poco a poco se imponía la devoción a la Virgen de Guadalupe como patrona de la ciudad y del virreinato ${ }^{27}$. Esto no quiere decir que su culto se extinguió, por demás, continuó siendo la abogada para pedir lluvias, intercesora en momentos de guerra y epidemias; también se le vinculó a las tempestades en el océano. A diferencia de Guadalupe que vino solo en una ocasión a la ciudad de México, La Remedios fue protagonista de más de setenta procesiones entre el siglo XVI y principios del XIX y sirvió de estandarte a los ejércitos realistas durante la Guerra de Independencia.

\section{La Gran Inundación y los santos dominicos}

Cuando entre enero y marzo de 1629 las autoridades de la ciudad de México se involucraron en la preparación de la fiesta de San Felipe de Jesús -primer santo mexicano originario de la capital- y en la ceremonia de inhumación de los restos del conquistador Hernán Cortés ${ }^{28}$, jamás se imaginaron que en

26. AHCM, Ayuntamiento de México, Actas de Cabildo, volumen 660-A, Libro 27, Acta de Cabildo del 27 de agosto de 1629, p. 124.

27. Algunas crónicas hablan de una procesión realizada durante la inundación. Según estos testimonios, La Remedios estuvo en catedral hasta 1634 junto a la Virgen de Guadalupe. Sin embargo, las actas de cabildo no dan ningún dato de ello.

28. Para ver el entierro de Hernán Cortés: AHCM, Ayuntamiento de México, Actas de Cabildo, Volumen 660-a, Libro 27, Acta del 23 de febrero de 1629, p. 49 y AHCM, 
el segundo semestre del año deberían hacer frente a la que probablemente significó la catástrofe más intensa que ha sufrido la ciudad de México en su historia. El día de San Mateo de 1629 un aguacero se precipitó sobre la capital. La inundación había destruido decenas de casas, había paralizado las actividades comerciales, había hecho colapsar los caminos y calzadas interrumpiendo la comunicación con tierra firme. El agua se había introducido en los conventos, edificios de gobierno y templos, afectando sus cimientos que amenazaban con derrumbarse ${ }^{29}$. Solo parte de la Plaza Mayor, la del Volador, una cuadra que comprendía el convento de Santa Teresa, la calle del Reloj, Montealegre y la Catedral se salvaron de los estragos del agua. Decenas de familias españolas abandonaron sus posesiones y buscaron amparo en los pueblos situados al margen de los lagos, otros prefirieron lugares lejanos como Puebla, Pachuca y San Luís Potosí ${ }^{30}$. Las familias más humildes, aquellas que hacían su vida en los barrios periféricos del centro de la ciudad, sucumbieron ante los derrumbes de sus viviendas, otras lograron escapar a lugares altos pero una buena parte quedó a merced de la anegación; incomunicados, se aventuraban al agua para evitar perecer a causa del hambre. Fue precisamente en estos lugares donde los estragos de la inundación duraron más tiempo. Los barrios indígenas de Santa Anta, Santa Catalina Mártir y San Francisco Tepito, lugares bastante poblados al norte de la ciudad, yacían desolados en $1635^{31}$. Del mismo modo, el barrio de la Santa Cruz y San Lázaro volvieron a la normalidad después de años. Hordas de despojados vagaban en las riberas de los lagos; sobrevivían cazando ranas y ajolotes, comiendo caracoles de agua y todo tipo de algas y plantas recolectadas en los pantanos. Los franciscanos intentaron congregar a los damnificados en el pueblo de San Miguel ${ }^{32}$,

Ayuntamiento de México, Actas de Cabildo, Volumen 660-a, Libro 27, Acta del 28 de febrero de 1629, p. 56. Para la celebración de San Felipe de Jesús: AHCM, Ayuntamiento de México, Actas de Cabildo, Volumen 660-a, Libro 27, Acta del 26 de enero de 1629, p. 43.

29. AHCM, Ayuntamiento de México, Actas de Cabildo, Volumen 660-a, Libro 27, Acta del 16 de octubre de 1629 , p. 149.

30. ISRAEL, 2005: 183. SOSA, 1883: 188. Alegre, 1842: 179. CAVO, 1836: 281.

31. AHCM, Ayuntamiento de México, Actas de Cabildo, Volumen 662-a, Libro 30, Acta del 6 de agosto de 1635, p. 40.

32. AHCM Ayuntamiento de México, Actas de Cabildo, Volumen 660-a, Libro 27, Acta del 18 de enero de 1630, p. 192. 
mientras el arzobispo enviaba a sus curas a oficiar los servicios religiosos en cualquier lugar donde se encontrara su rebaño ${ }^{33}$.

La vida durante la inundación debió ser difícil. Centenares de canoas, chalupas y otras embarcaciones fueron llegando a la ciudad, provenientes de los pueblos lacustres del sur ${ }^{34}$. Las misas y procesiones ${ }^{35}$, la distribución de alimentos, el rescate a los damnificados ${ }^{36}$, la venta de pan y carne se hacía en canoas ${ }^{37}$. Se mandaron a construir calzadillas de tierra levantadas algunos centímetros sobre el agua para permitir el pasó a pie en calles y plazas ${ }^{38}$, se intentó limpiar las acequias y canales para que sirvieran de caños ${ }^{39}$, se construyeron una serie de bombas movidas por mulas y negros para desaguar las principales calles y edificios ${ }^{40}$ pero el agua daba poca tregua. Cuando parecía que la procesión del día de Corpus de 1630 podía hacerse a pie, un aguacero acabó con las esperanzas de los vecinos. No solo se perdió los pocos espacios libres de agua, sino que la ciudad se volvió a inundar tal como estaba el año anterior.

La crisis trajo consigo una lluvia de santos que poco a poco comenzaron a aparecer durante y después de la inundación. Algunas corporaciones levantaron la mano para proponer intercesores; buscaron que las imágenes vinculadas a sus agrupaciones fueran reconocidas como las grandes salvadoras de la ciudad. Empezó una lucha donde las armas fueron los santos y su participación durante el desastre ocasionado por la inundación. Dentro del

33. En enero de 1630 los curas seglares entraron en conflicto con los frailes dominicos de Coyoacán pues habían ido a oficiar hasta sus jurisdicciones sin permiso. Archivo General de Indias, Gobierno, Audiencia de México, Cartas y expedientes del virrey, Carta del virrey marqués de Cerralvo, ES.41091.AGI/23.10.30//MEXICO,30,N.30, foja 3 recto. Disponible en http://pares.mcu.es [consultado el 14 de noviembre de 2014]

34. GIBSON, 2007: 244.

35. AlEGRE, op. cit. p. 180. Descripción de una procesión durante la inundación de 1629: SOSA, op., cit., pp. 191-192.

36. VETANCURT, 1697: 121.

37. AHCM, Ayuntamiento de México, Actas de Cabildo, Volumen 660-a, Libro 27, Acta del 22 de septiembre de 1629, p. 140.

38. AHCM, Ayuntamiento de México, Actas de Cabildo, Volumen 660-a, Libro 27, Acta del 16 de octubre de 1629 , p. 149

39. Cepeda, Carrillo y Álvarez, op. cit., foja 66 verso.

40. AHCM, Ayuntamiento de México, Actas de Cabildo, Volumen 660-a, Libro 27, Acta del 9 de marzo de 1630, p. 215. 
clero regular sobresale la participación de la Orden de Predicadores quienes propusieron varias imágenes ligadas a su corporación, entre ellas, su santo titular Domingo de Guzmán.

El 31 de julio de 1630 el prior de la orden dominica, fray Juan de Córdova, envió al cabildo una carta donde se excusaba por no poder ayudar a los regidores «en la aflicción y trabajo en que se halla de la inundación si no es pedir a Nuestro Señor mire con ojos de piedad esta ciudad intercediendo nuestro padre Santo Domingo». El religioso, además, señalaba que Santo Domingo «parece que legítimamente le debe vuestra señoría advocar por su patrón para este trabajo e inundación», por lo que su festividad próxima debía hacerse con todo lucimiento y devoción ${ }^{41}$. Los regidores aceptaron el ofrecimiento y declararon al santo

[...] con muy buena gana y de todo corazón por su patrón al gran patriarca Santo Domingo y agradece y estima el acuerdo y advertencia que para ello le hace el padre prior de su convento y en esta conformidad se haga escritura de capitulaciones para el dicho patronazgo suplicando al santo sea intercesor con la divina majestad para que alce la mano del rigor de estas inundaciones que conoce la ciudad por los pecados de ella usando de su infinita misericordia y clemencia y todos los años se celebre su fiesta y se acuerda los días que se propone por el padre prior y se dé la cera necesaria ${ }^{42}$.

Santo Domingo fue el primer santo patrono contra las inundaciones que no tenía ninguna relación con el agua, más bien, se le reconoció como tal por razones políticas, pues en plena crisis, los dominicos servían de gran apoyo a las autoridades y participaban en las decisiones para enfrentar el problema. Algunos años después, el cronista de la orden fray Alonso Franco, testigo presencial de la inundación, enarbolaba ciertos sucesos ocurridos durante la catástrofe relacionados con imágenes religiosas vinculadas a los dominicos. Según el religioso, además de Santo Domingo, los frailes dominicos buscaron la intercesión de la Virgen del Rosario, patrona de la orden e imagen vinculada a la vida y milagros de Domingo de Guzmán a la que se le hicieron rogativas y organizaron novenarios. También narraba que, en el convento de monjas dominico de la capital novohispana, el monasterio de Santa Catarina de Siena,

41. AHCM, Ayuntamiento de México, Actas de Cabildo, Volumen 660-a, Libro 27Acta de Cabildo del 31 de julio de 1630, pp. 261 y 262.

42. Ibídem, p. 262. 
adjunto al convento de Santo Domingo y a las Casas del Santo Oficio, ocurrió un milagro inesperado antes de la inundación. Una monja tuvo una premonición mientras se encontraba orando frente a la imagen de la Virgen del Rosario en la sala de Domina.

[...] vio a la ciudad de México anegada, y entre nubes espesas se le representó Cristo Señor Nuestro Crucificado, el cual apenas se divisaba, y delante de este Divino Señor la Reina del cielo, María Santísima su madre, puesta las manos y muy afligida pidiendo misericordia para México; y vio que delante de la virgen Santísima estaban millares de gentes que con lágrimas la pedían su favor y misericordia, y la oración que decían era: "Recordare Virgo Mater», etc., en que pedían intercediese por ellos y detuviese la justa indignación que su precioso Hijo tenía contra ellos. Obligada la Madre de piedad de estas súplicas, instaba pidiendo a su Santísimo Hijo perdón para los que se valían de su patrocinio y amparo. En esto oyó como de entre las nubes una voz que dijo: «No lo hundiré, pero se quedará así» ${ }^{43}$.

Una vez ocurrió la inundación, la monja dijo lo de su visión y también señaló que para pedir la intercesión de la Madre de Dios era necesario hacer una misa consagrada a la Virgen de La Piedad y en ella, todas las monjas del convento debían cantar la antífona Recordare Virgo Mater Domini. A pesar de que no se encontraron los papeles que contenía dicha antífona y nadie se la sabía de memoria, aquella monja se inspiró y cantó en trance tal como ella misma lo había dicho. Al igual que la Virgen del Rosario, la Virgen de la Piedad era una imagen asociada con la Orden de Predicadores de Santo Domingo. En México tenía un santuario extramuros, que también servía de Casa de Observancia a los frailes dominicos en el pequeño pueblo de La Piedad que quedaba de camino a Coyoacán y Tacubaya. De hecho, al igual que la pintura en el ayate donde se plasmó la imagen de la Virgen de Guadalupe, la pintura de Nuestra Señora de La Piedad, se le considera milagrosamente pintada por las manos de Dios.

Otro relato que nos cuenta fray Alonso Franco tenía que ver con una sirvienta ciega de aquel mismo convento de Santa Catarina de Siena. Aquella mujer también fue protagonista de un milagro relacionado a las inundaciones. Se contaba que aquella buena y devota anciana asistía después de sus labores a la Sala de Domina para orar en la presencia de la Virgen del Rosario.

43. FRANCO, 1900: 455.

Revista de Historia Moderna, n. 35 (2017) (pp. 149-177) | ISSN-e: 1989-9823 | ISSN: 0212-5862 
En eso estaba un día cualquiera durante la gran inundación, cuando entró a la habitación otra religiosa y la ciega le preguntó: «Madre, ¿A dónde han llevado a mi Señora la Virgen, que viene toda llena de lodo y zarpas? Y aquí ha habido unas sillas muy ricas de tela, y tres personas han dicho que no se hundirá México ${ }^{44}$. La monja se acercó a explorar la imagen de la virgen y la halló con las ropas gastadas y hechas zarpas. Según Franco, el milagro fue tan conocido que mucha gente guardaba trozos del vestido de la virgen como reliquias. En plena inundación, los fieles pensaban que Nuestra Señora del Rosario había salido a asistir a los más menesterosos.

Los supuestos milagros documentados por el cronista fray Alonso Franco pueden interpretarse como un esfuerzo de la orden dominica por no sucumbir a una política que se venía gestando desde finales del siglo XVI. A partir de los concilios mexicanos y de la actuación del primer arzobispo secular que hubo en Nueva España, Pedro Moya de Contreras, la Corona buscaba posicionar al clero secular en detrimento del clero regular ${ }^{45}$. Una expresión de esta política fue la Ley de examinación de las parroquias de indios, que permitía a las autoridades eclesiásticas suspender las actividades de los frailes en sus zonas de influencia a partir de comprobar que no estaban calificados para evangelizar a los indios de sus parroquias. El examen consistía, entre otras cosas, en que los religiosos supieran las lenguas de los indios, asunto difícil pues muchos de ellos provenían de Europa a diferencia de los curas párrocos que se habían formado en la Nueva España. De este modo, la normatividad permitía la intervención del clero secular, por medio de los curas párrocos quienes podían sustituir a los frailes en los pueblos de indios ${ }^{46}$. En realidad, la secularización representaba una serie de beneficios económicos para la Corona pues no solo permitía sufragar el mantenimiento del clero y

44. Ídem.

45. MARTínez LÓPEZ-CANO.

46. En 1635, nos dice Virve Piho, tan solo en el obispado de Puebla había setecientos sacerdotes del clero secular desocupados pues en aquella provincia las parroquias estaban bajo el control de los frailes que, además, muchos de ellos tenían origen europeo. La secularización de las parroquias, además de atender el problema económico, podría dar trabajo a una fila enorme de religiosos desocupados. Ver en PIHO, 1977: 84. 
la construcción de nuevas parroquias, sino que permitía la entrada de dos novenos del diezmo a las arcas reales ${ }^{47}$.

A pesar de los ánimos de las autoridades españolas, estas políticas no pudieron implementarse con facilidad. Hubo fuerte oposición por parte de las órdenes religiosas que veían la secularización como una amenaza a sus corporaciones. A principios del siglo XVII, franciscanos, dominicos y agustinos, principalmente, buscaron apoyo en algunas autoridades y en ocasiones lograron las simpatías de virreyes quienes veían a los frailes como aliados frente al clero secular encabezado por los arzobispos ${ }^{48}$. Durante esta época nace un tipo de crónica religiosa que pretendía justificar la presencia de las ordenes en Nueva España, enarbolar a sus santos varones y exponer los esfuerzos de los frailes en las tareas de evangelización. Las crónicas provinciales de órdenes religiosas, según Rosa Camelo, tenían esa característica; eran una especie de relaciones de méritos y servicios corporativos, una suerte de propaganda oficial de las ordenes cuyo objetivo era abonar argumentos a favor de los frailes ${ }^{49}$.

En el caso dominico, la gran obra propagandística fue iniciada a finales del siglo XVI por fray Agustín Dávila Padilla quien había cimentado un discurso a favor de la Orden de Predicadores a partir de enarbolar la actuación de los frailes en la evangelización, llegando a comparar la vida y muerte de estos con la de los santos, especialmente con la construcción de la figura de fray Domingo de Betanzos, el primer líder de la orden en México ${ }^{50}$. La obra de fray Alonso Franco es una continuación del discurso iniciado por Dávila, se titula Segunda Parte pues fue redactada para actualizar la relación de méritos y servicios publicada en 1597 y escrita por Dávila. Franco ya no centra su discurso alrededor de fray Domingo de Betanzos, busca nuevas formas de exaltar a la orden dominica. Una de ellas estuvo relacionada, sin duda, a los santos y vírgenes vinculados a los dominicos que Franco asegura pudieron interceder por la ciudad de México durante la inundación de 1629.

47. RODRÍGUEZ KuRI, 1990: 198.

48. Jonathan Israel esquematiza los conflictos del siglo XVII a partir de la identificación de dos bandos: el burocrático, encabezado por el virrey y acompañado por los corregidores y los frailes; y el criollo que era liderado por los arzobispos, los curas párrocos, la población española nacida en México y el cabildo secular.

49. CAmelo, 1996: 169-170.

50. La obra se titula Historia de la Provincia de Santiago de México. 
Franco postula su abanico de imágenes religiosas en un momento tenso. Se sabe que se le encomendó la tarea de continuar la obra de Dávila Padilla en 1637 y la presentó en el Capítulo de la Orden de 1645. Apenas cinco años atrás, el 29 de diciembre de 1640, mientras Franco redactaba su obra, había ocurrido un hecho extraordinario en la historia novohispana: el obispo de Puebla, Juan de Palafox y Mendoza, había encabezado un contingente de jinetes laicos y eclesiásticos y había tomado por la fuerza la ciudad de Tlaxcala. A partir de ese día comenzó el proceso de secularización que hasta esos años se había mantenido estancado. Para febrero de 1641, Palafox les había arrebatado a los frailes 35 parroquias, siendo los franciscanos los más afectados pues habían perdido 30, los dominicos tres y los agustinos dos y, aunque los hijos de Santo Domingo no se habían visto tan perjudicados, en otras regiones del virreinato los obispos seculares amenazaban con imitar las acciones de Palafox. Así, en el bastión dominico de Oaxaca, el obispo amenazaba con iniciar por la fuerza la secularización de las parroquias ${ }^{51}$.

En síntesis, la postulación de santos patronos vinculados a los dominicos y que se les adjudicó una participación relevante como intercesores de la ciudad durante la inundación de 1629, fue una estrategia política de la orden dominica para defender sus intereses en una coyuntura caracterizada por el inicio del proceso de secularización de las parroquias. Los dominicos pretendían, con la crónica oficial de Franco, que sus santos fueran reconocidos como los mejores intercesores ante el peor desastre que había sufrido la ciudad; eran parte de la propaganda utilizada por los frailes para defender sus intereses y territorios. Los intentos fueron, a fin de cuentas, infructuosos, pues al norte de la ciudad, una virgen mestiza de manto verdoso y azulado, como el color del agua de los lagos, se entronizó como la gran ganadora de la lucha de los santos. Desgraciadamente para los dominicos, aquella virgen morena no estaba dentro de su abanico de imágenes milagrosas.

\section{La respuesta del clero secular}

Aún antes de que la Virgen de Guadalupe fuera la imagen reconocida por todos como la «gran intercesora» de la ciudad de México frente a las inundaciones,

51. ISRAEL, op. cit., p. 234. 
los miembros del clero secular, que por entonces habían cobrado mayor relevancia en el abanico de corporaciones novohispanas, habían intentado hacerse de una imagen religiosa simbólica e importante. En muchos aspectos, los seculares estaban en desventaja frente al clero regular. Mientras que los frailes llegaban en barco desde Europa, los miembros del clero secular tenían que formarse en Nueva España, lo que implicaba la instauración de instituciones educativas para forjar a los curas y demás religiosos seculares ${ }^{52}$. El clero secular crecía lentamente y a principios del siglo XVII el clero regular era más numeroso e influyente, tenía la mayoría de las parroquias de indios y sus miembros participaban con mayor vigor en la vida social y política del virreinato. Las órdenes religiosas, además, habían construido a lo largo del siglo XVI todo un aparato simbólico a través de los santos. Los dominicos, como se ha dicho, contaban con Santo Domingo, Santa Catarina de Siena y las Vírgenes del Rosario y La Piedad; los franciscanos tenían a San Francisco de Asís, Santiago y Santa Clara; y los agustinos a San Agustín, Santa Mónica y San Nicolás Tolentino. El clero secular carecía de una imagen religiosa de tal nivel, deambulaba sin amparo de un santo particular representativo por lo que durante un tiempo intentaron buscarlo.

En 1621, cuando el arzobispo de México, Juan Pérez de la Serna, organizaba una misión apostólica en algunos pueblos de indios de la jurisdicción de Tacuba y avisaba a los regidores su deseo de dormir en la ermita de los Remedios, el cabildo en pleno y en compañía de sus abogados, redactaron un inquietante documento donde invitaban al prelado a no visitar la ermita argumentando que «desde la fundación y erección de la ermita de nuestra señora de los remedios los señores arzobispos sus antecesores ni otra persona en su nombre nunca han visitado dicha ermita ${ }^{53}$. Apelaron a un caso semejante cuando el arzobispo Moya de Contreras deseaba ir a la ermita pero claudicó ante la insistencia de los regidores. En realidad, lo que podemos apreciar en la actitud del ayuntamiento es una profunda y justificada desconfianza, pues temían que la presencia de Pérez de la Serna en Naucalpan fuera parte de una estrategia para arrebatarles el patronato de la virgen. Este temor no era

52. Ріно, op. cit., pp. 82-83.

53. AHCM, Ayuntamiento de México, Actas de Cabildo, volumen 659-A, Libro 24, Acta de Cabildo del 15 de abril de 1621, p. 59. 
infundado, puesto que, durante las continuas procesiones donde se llevaba la imagen a catedral, las autoridades del clero secular buscaban ser protagonistas cuando no les correspondía. Los regidores sospechaban un ánimo de intromisión en sus asuntos que podía desencadenar la perdida de la jurisdicción de la ermita y de su milagrosa imagen. Por demás, ya en el siglo XVI los regidores habían pugnado con los franciscanos quienes también deseaban ostentar el patronato de la Virgen de los Remedios. En 1589 las tensiones aumentaron cuando el virrey Marqués de Villa Manrique cedió la imagen a los religiosos, pero un regidor de nombre Alonso de Valdés se anticipó, hurtó la imagen y la escondió en la catedral. Valdés estuvo preso treinta días sin decir en donde había escondido la escultura de la virgen ${ }^{54}$. En fin, los regidores hicieron todo lo posible para evitar que el arzobispo fuera a su ermita y esto nos deja percibir un deseo, entrelíneas, por parte del clero secular por apropiarse de la imagen.

Finalmente, Pérez de la Serna encontró lo que buscaba en un pequeño pueblo minero al norte, de la Cuenca de México, donde halló un cristo crucificado que, según algunos relatos, era muy milagroso. El Señor de Mapethe, Cristo Milagroso de Ixmiquilpan o Cristo de Santa Teresa fue una imagen que se le consideró extraordinariamente prodigiosa desde principios de siglo XVII cuando empezó a hacer milagros en un rincón del actual Estado de Hidalgo. No solo se regeneró milagrosamente cuando el sacerdote de la parroquia decidió enterrarlo con el primer muerto que hubiera en el pueblo, sino además se le acreditaba su efectividad en las epidemias y otros milagros como el hecho de que nadie moría en Mapethe. El cristo fue traído a la ciudad por órdenes del arzobispo Pérez de la Serna, que buscaba dotar al nuevo convento de Carmelitas Descalzas de una imagen importante para el culto. Así, en el traslado no solo se presentaron tumultos y desavenencias, sino que el cristo pasó un tiempo en Ixmiquilpan porque, durante su traslado a México, fue imposible levantarlo de ese lugar. La devoción a esta imagen fue particularmente intensa, sobre todo durante el siglo XVII, pero con el paso de los años fue quedando en el olvido al extremo que hoy casi nadie lo recuerda y muchos ignoran su paradero actual. Empero, hay muchas pinturas de aquel cristo que solían estar en las casas de las personas más importantes de la ciudad, libros y documentos que hablan de él.

\footnotetext{
54. MiRAnda GodínEZ, 2001: 136.
} 
Según una tradición, el cristo empezó a sudar unos días antes del aguacero del día de San Mateo de 1629. Como presagio de la desgracia, además, las campanas del Templo de Santa Teresa del Convento carmelita de San José sonaban sin saber quién las tocaba. Las transpiraciones de la imagen eran de agua y sangre y esto se interpretó como el anuncio de que algo ocurriría en la ciudad "dentro de muy breve tiempo». Alfonso de Velasco, estudioso de la imagen, comparaba estas señales con aquellas que manifestó el Cristo Crucificado de la ciudad gaditana de Aurelia, urbe arrasada tiempo después por el fuego: «La calamidad de México fue verse afligida de copiosísimos raudales de agua que la inundaron, pero no la destruyeron; allí fue todo rigor, todo justicia; aquí fueron grandes los amagos, más con mucha misericordia ${ }^{55}$.

Velasco cuenta cómo la monja fundadora del convento de San José, sor Inés de la Cruz, famosa porque la poetisa sor Juana Inés de la Cruz tomó su nombre, solía rezar frente a la imagen para suplicarle «se sirviese de aplacar su indignación, y templar los rigores de su divina justicia, que tan merecidos tenía esta ciudad por sus muchas y muy graves culpas». Un día que rezaba con particular fervor, la monja experimentó una visión: Jesucristo estaba con mirada de Juez severo; a su derecha se hallaba la Virgen y a su izquierda Santa Catalina Mártir «intercediendo esta con la madre y la madre con el hijo para que se apiadase de esta ciudad devotísima suya ${ }^{56}$. Jesús entonces le dijo a sor Inés:

Merecido tiene esta ciudad y merecido tienen los de ella el último castigo que deliberé en el Tribunal de mi justicia contra ellos, basta acabarla con esta inundación, como lo hice con la del Diluvio del Mundo; pero los ruegos de mi Madre han detenido hasta hoy el brazo para que no descargue de una vez el golpe de las aguas sobre de ella, y ahora me obligan a levantar la mano del todo, y a mandar a las olas ejecutoras de mi justicia que se retiren y no la acaben. Díselo así de mi parte a tu Confesor para que se lo notifique al Arzobispo, y sepan los de México que por respeto de mi Madre no acabo con esta Ciudad, que le agradezcan este beneficio, y que se parten de ofenderme por su amor, pues yo por amor de ella me aparto de castigarlos ${ }^{57}$.

55. Velasco, op. cit. p. 79.

56. Ibídem., p. 80.

57. Ibídem., p. 81. 
Para Velasco, la ciudad de México no había corrido con la misma suerte que Aurelia debido al patrocinio que tuvo de varios abogados, principalmente la Virgen María, Santa Catalina Mártir y el Señor San José. Especialmente llama la atención Santa Catalina Mártir, pues aquella santa era la patrona de la primera parroquia secular en un barrio indígena de la ciudad de México, precisamente, el barrio de Santa Catalina Mártir se hallaba al norte, entre Tepito y el barrio de Santo Domingo. En otras palabras, era una santa vinculada al clero secular. San José era el patrono del convento carmelita de Santa Teresa, corporación alentada por el propio arzobispo Pérez de la Serna. En fin, las imágenes postuladas por el clero secular también estaban vinculadas a la orden carmelita, asunto que merece un estudio profundo ${ }^{58}$. En el relato de Velasco sobresale también las palabras proferidas por Jesucristo a la monja y donde se reconoce al arzobispo como la principal autoridad religiosa de la ciudad.

El clero secular postuló a la gran ganadora de esta lucha: la Virgen de Guadalupe. La imagen era auténticamente mexicana, su manto azul verdoso podía recordar el color de las aguas y su ermita se hallaba a un costado del lago, en otras palabras, la virgen estaba profundamente relacionada al agua. Entre los milagros adjudicados a ella, estaba aquel donde hizo brotar un manantial entre las piedras secas del cerro del Tepeyac y ante la presencia del indio Juan Diego. A los ojos de los creyentes, este milagro representaba la señal más grande de amor de la divinidad para con la ciudad de México ${ }^{59}$.

Las crónicas de la Gran Inundación hacen mención de una procesión donde se trajo a la ciudad la imagen guadalupana haciendo uso de embarcaciones, pero es probable que estas ideas hayan sido el resultado de un proceso donde el clero secular intentó situar a la virgen como la imagen más efectiva contra las inundaciones. La mayoría de los autores, por ejemplo, hablan que la procesión fue entre 1629 y 1630, pero olvidan mencionar que el agua comenzó a disminuir hasta 1634 y en algunas partes posteriormente. Algunas crónicas señalan que la Guadalupana y Remedios permanecieron años en la ciudad hasta que el agua bajó. Es probable que la procesión no se hubiera llevado a cabo tal cual lo dicen estas crónicas, pues en los documentos del

58. ISRAEL, op., cit., p. 140.

59. MUSSET, 1992: 31.

Revista de Historia Moderna, n. ${ }^{\circ} 35$ (2017) (pp. 149-177) | ISSN-e: 1989-9823 | ISSN: 0212-5862 
momento no se menciona y también cabe la posibilidad de que, años después de la inundación, surgiera la idea de que aquella procesión había sido suficiente para aplacar la ira de Dios, convirtiendo a la Virgen de Guadalupe en la advocación más efectiva por encima de San Gregorio Taumaturgo y la Virgen de los Remedios a la que se le encomendó la tarea de interceder para que las epidemias posteriores a la inundación mermaran.

Estamos frente a un problema difícil pues la devoción guadalupana pudo estar influenciada por aquello que se escribió años después de la inundación. Todo pudo haber comenzado después de la publicación, en 1648, del libro Imagen de la Virgen María, Madre de Dios de Guadalupe, Milagrosamente aparecida en la Ciudad de México, del clérigo Miguel Sánchez, obra considerada como una de las más importantes e influyentes del México colonial. Ahí, el autor sembró una idea muy poderosa pues planteaba, por primera ocasión, que la inundación «Remediase con el favor é intercesión de la Virgen MARIA Señora Nuestra, viniendo a la ciudad su santa imagen de Guadalupe, a donde se volvió dejándola seca y libre de las aguas [...] como habiendo padecido la Ciudad tantas inundaciones, en ninguna se valió de esta Reliquia, e Imagen milagrosa ${ }^{60}$. A partir de ese momento, diversas obras que hablaban del mito fueron publicadas durante la segunda mitad del siglo XVII. Para el siglo XVIII la Virgen de Guadalupe se había convertido en la imagen más venerada de la Nueva España. Empero, esto no fue siempre así, pues Antonio Robles escribía en 1674 que la imagen de la virgen de Guadalupe estaba relegada casi del todo

[...] aún de los vecinos de México hasta que este venerable sacerdote [Miguel Sánchez] la dio a conocer, pues no había en todo México más que una imagen de esta soberana señora en el convento de Santo Domingo y hoy no hay convento ni iglesia donde no se venere, y rarísima la casa o celda de religioso donde no esté su copia universalmente en toda la Nueva España ${ }^{61}$.

De ser cierto lo escrito por Robles, estamos frente a la construcción política de una devoción, utilizada por el clero secular que tenía la custodia de la imagen, para ganar mayor influencia en la vida social novohispana. Es probable que la virgen de Guadalupe no fuera lo que hoy es sin este discurso y, por supuesto, si no hubiera ocurrido el desastre que implicó la Gran Inundación

60. SÁNCHEZ, 1648: 61.

61. Citado en ISRAEL, op. cit.p. 63. El énfasis es mío.

Revista de Historia Moderna, n. 35 (2017) (pp. 149-177) | ISSN-e: 1989-9823 | ISSN: 0212-5862 
de 1629. Es probable que la devoción guadalupana sufriera un cambio a partir de que se le adjudicó el milagro de detener la inundación. El culto a la virgen existía desde mediados del siglo XVI, pero se caracterizaba por ser predominantemente indígena, incluso, fray Bernardino de Sahagún condenaba las peregrinaciones al cerrito del Tepeyac pues en ellas había notado que los indios expresaban practicas idolátricas ${ }^{62}$. Pues bien, al convertirse en la patrona contra las inundaciones, la imagen ganó nuevos adeptos de otros estamentos, pues el milagro impactó en todas las esferas y grupos sociales del virreinato empezando por los de la ciudad de México. Así, la Guadalupana se fue convirtiendo en símbolo de algo que se puede entender como eminentemente novohispano. Surgió una especie de "patriotismo mexicano» o "protonacionalismo», quizás embrionario, pero que se desarrollaba en la medida en que la virgen se convertía, primero, en patrona del clero secular, «luego en la de la ciudad y, en el transcurso del siglo XVIII, de todo el país ${ }^{63}$.

Entendido como un proceso progresivo, el inicio podría establecerse cuando Nuestra Señora de Guadalupe fue aceptada por consenso como la gran intercesora y patrona de la ciudad contra las inundaciones, aunque también hay que señalar que es difícil saber hasta qué grado la ocurrencia de la gran inundación contribuyó en la entronización de la Virgen de Guadalupe. Finalmente, el triunfo de la virgen también trae implícita una victoria para el clero secular en un momento donde los enfrentamientos entre el clero estaban a la orden del día. Pero, además, la adopción de la imagen como patrona de México conlleva estudiar un abanico de cosas de suma relevancia: En este espacio lacustre, donde los hombres hacían abominaciones en nombre de falsos dioses y demonios; una tierra manchada de sangre y pecados; la aparición de una virgen amorosa, mestiza y mexicana mostraba a los ojos del mundo que México y su ciudad estaban otra vez en los planes de Dios. Al salvar a la ciudad de la inundación, la virgen también se comenzó a convertir en un símbolo muy importante para las siguientes generaciones.

62. BRADING, 2003: 143.

63. GRUZINSKI, 2005: 543.

Revista de Historia Moderna, n. ${ }^{\circ} 35$ (2017) (pp. 149-177) | ISSN-e: 1989-9823 | ISSN: 0212-5862 


\section{Bibliografía}

Alegre, P. Francisco Javier, Historia de la Compañía de Jesús en Nueva España al tiempo de su expulsión, Tomo II, México, Impreso por J. M. Lara, 1842. Disponible en: http://www.cervantesvirtual.com/nd/ark:/59851/bmcb85k5 [consultado el 21 de septiembre de 2016]

Benavente, fray Toribio de, Historia de los Indios de la Nueva España, Barcelona, Ediciones Juan Gili, 1914. Disponible en: https://archive.org/details/historiadelosind00moto [consultado el 12 de noviembre de 2016]

BOYER, Richard Everett, La gran inundación. Vida y sociedad en México (16291638), México, Secretaría de Educación Pública, 1975.

BRADING, David, Orbe Indiano. De la monarquía católica a la república criolla, 1492-1867, México, FCE, 2003.

CAmelo, Rosa, «Las crónicas provinciales de órdenes religiosas» en Brian F. Connaughton y Andrés Lira González (coord.), Las fuentes eclesiásticas para la Historia Social de México, México, UAM/Instituto Mora, 1996.

CAVO, P. Andrés, Los tres siglos de México durante el gobierno español hasta la entrada del ejército trigarante, Tomo I, México, Luis Abadiano y Valdés, 1836. Disponible en: https://books.google.com.mx [consultado el 8 de octubre de 2009]

CePedA, Fernando de, Carrillo, Fernando Alonso y Álvarez Serrano, Juan de, Relación Universal legítima y verdadera del sitio en que está fundada la muy noble, insigne y muy leal Ciudad de México, México, CONDUMEX, 1982.

CiRuelo, Pedro, Tratado en el cual se representan todas las supersticiones y hechicerías, Barcelona, Sebastián de Cormellas, 1628. Disponible en: http://www. memoriachilena.cl/602/w3-article-9871.html [consultado el 15 de diciembre de 2009]

CisNeros, fray Luis de, Historia del principio, origen, progresos y venidas a México y milagros de la Santa Imagen de Nuestra Señora de los Remedios, extramuros de México, México, El Colegio de Michoacán, 1999.

Dávila Padilla, Agustín, Historia de la Provincia de Santiago de México, Bruselas, Casa de Francisco Vivien, 1648. Disponible en: https://books.google.com.mx [consultado el 6 de marzo de 2013]

DURÁn, Fray Diego, Historia de las Indias de Nueva España e Islas de Tierra Firme. Tomo I, México, Andrade y Escalante, 1867. Disponible en: http://www.cervantesvirtual.com/nd/ark:/59851/bmck0706 [consultado el 17 de febrero de 2016] 
Fernández de ECheVerría y Veytia, Mariano, Baluartes de México. Descripción histórica de las cuatro milagrosas imágenes de Nuestra Señora, que se veneran en la Muy Noble, Leal e Imperial Ciudad de México, México, Alejandro Valdés, 1820. Disponible en: https://books.google.com.mx/books/about/Baluartes_ de_Mexico.html?hl=es\&id=uo6ljz8v5moC\&redir_esc=y [consultado el 13 de diciembre de 2016]

Franco, fray Alonso, Segunda Parte de la Historia de la Provincia de Santiago de México. Orden de predicadores de la Nueva España, México, Imprenta del Museo Nacional, 1900. Disponible en: http://cdigital.dgb.uanl.mx/ la/1080017668/1080017668.html [consultado el 1 de septiembre de 2014] GIBSON, Charles, Los aztecas bajo el dominio español 1519-1810, México, Siglo XXI, 2007.

GRUZINSKI, Serge, «Las imágenes, los imaginarios y la occidentalización» en Marcello Carmagnani, Alicia Hernández Chávez y Romano Ruggiero (coords.), Para una historia de América I. Las estructuras, México, FCE/ COLMEX, 2005.

ISRAEL, Jonathan, Razas, clases sociales y vida política en el México Colonial [16101670], México, FCE, 2005.

MARTíneZ, Enrico, Repertorio de los tiempos e Historia Natural de esta Nueva España, México, Imprenta del mismo autor, 1606. Disponible en: https:// books.google.com.mx [consultado el 9 de septiembre de 2009]

Martínez LóPez-CANO, María del Pilar, Concilios provinciales mexicanos. Época Colonial, México, UNAM/IIH, 2004.

Miranda GodíneZ, Francisco, Dos cultos fundantes: Los Remedios y Guadalupe (1521-1649), Zamora, El Colegio de Michoacán, 2001.

Musset, Alain, El Agua en el Valle de México siglos XVI-XVIII, México, Pórtico de la Ciudad de México, 1992.

Musset, Alain, Ciudades nómadas del Nuevo Mundo, México, FCE, 2011.

NOLASCO, Margarita, «Cuauhtlancingo, un pueblo de la región de Cholula» en Ignacio Marquina (coord.), Proyecto Cholula, México, INAH, 1970.

PiHo, Virve, «La secularización de las parroquias y la economía eclesiástica en la Nueva España», en Journal de la Société des Americanistes, 64/1(1977): 81-88. http://dx.doi.org/10.3406/jsa.1977.2145

RiBADENEYRA, Pedro de, Flos Sanctorum, Sexta parte en que contienen las vidas de los santos, que pertenecen a los meses de noviembre y diciembre, Madrid, Imprenta 
de don Gabriel del Barrio, 1716. Disponible en: https://books.google.com. mx_[consultado el 11 de agosto de 2009]

RODRíGUEz KuRI, Ariel, «Juan de Palafox y Mendoza: la subversión institucional» en La Palabra y el Hombre, 73 (1990): 190-207. Disponible en: http://cdigital. uv.mx/handle/123456789/1771

SAHAGÚn, fray Bernardino de, Historia General de las Cosas de la Nueva España, México, Porrúa, 1992.

SÁNCHEZ, Miguel. Imagen de la virgen María, Madre de Dios de Guadalupe, milagrosamente aparecida en la Ciudad de México. México, Imprenta de la viuda de Bernardo Calderón, 1648. Disponible en: https://books.google.com.mx [consultado el 9 de septiembre de 2009]

SigÜEnZA y GóngORA, Carlos, «Alboroto y motín en México del 8 de junio de 1692», en Relaciones Históricas, México, UNAM, 1972.

SosA, Francisco, Efemérides históricas y biográficas, T. II, México, Gonzalo A. Esteva, 1883. Disponible en: http://cdigital.dgb.uanl.mx/la/1020001585/1020001585. PDF [consultado el 3 de agosto de 2016]

TORQUemadA, fray Juan de, Monarquía indiana de los veinte y un libros rituales y monarquía indiana, con el origen y guerras de los indios occidentales, de sus poblaciones, descubrimiento, conquista, conversión y otras cosas maravillosas de la misma tierra, vol. II, México, UNAM/IIH, 1975.

VELASCO, Alfonso Alberto de, Historia de la milagrosa Renovación de la Soberana Imagen de Cristo Señor Nuestro Crucificado, que se venera en la Iglesia del Convento de Santa Teresa la Antigua, México, 1845. Disponible en: https:// books.google.com.mx [consultado el 17 de mayo de 2016]

Vetancurt, fray Agustín de, Crónica de la Provincia del Santo Evangelio de México. Cuarta parte del Teatro Mexicano de los sucesos Religiosos, México, Viuda de Ribera 1697. Disponible en: https://books.google.com.mx [consultado el 3 de enero de 2011] 